\title{
RELATIONS BETWEEN CENTRAL GOVERNMENT AND LOCAL GOVERNMENT IN KOSOVO
}

\section{Iliriana BAJRAMI, LLM.}

Rezonanca College, Faculty of Nursing, Ilirana.bajrami@rks-gov.net

\begin{tabular}{l}
\hline Article history: \\
Accepted 17 July 2019 \\
Available online 24 August 2019 \\
Keywords: \\
Authorizations, \\
Central Govenrment \\
Consitution \\
Competences \\
Decentralization \\
Local Government \\
Local governance \\
Power
\end{tabular}

\begin{abstract}
A b s t r a c t
This paper represents a model attempt to shed light on institutional relations between two levels of power in the Republic of Kosovo. The wide range of legal acts concerned with the regulation of the reports between Central and Legal Government in Kosovo, comprise a legal system containing complex set of rules which define the share of power, competences and the authority of these two levels. As such, this paper is an attempt to investigate and analyze the complex set of legal and institutional mechanisms referring to relations between these two levels of power.
\end{abstract}

The paper follows a set of approaches and methods such as comparative and analytical method, descriptive, empirical and historical method in order to cover as much aspects and elements of the relations between two levels of power in Kosovo.

\section{Introduction}

Reports between the Central and Local Government are an everpresent and important issue for the functioning of state power. Historically, there has always been disagreement between these two levels of power, which consisted in the claims of Local Government to have as much powers as possible, while on the other hand, at the same time it has been accompanied by the efforts of the Central Government to retain its powers and responsibilities for the central level of power.

Even nowadays, Central and Local Government relations are very important and current issues in nearly all countries, regardless of the form of governance and the level of democracy. Particularly in transition countries emerging from the communist dictatorship, these relations have been of significant importance given that the relations between these levels of power have been based on the principle of hierarchy and subordination.

Regarding Kosovo, after the first local elections in 2000 until the adoption of the Constitution and the Law on Local SelfGovernment, the relations between these two levels of power were not legally regulated and institutionalized. Regulation 45/2000 on Self-Government of Kosovo Municipalities did not foresee protection mechanisms of local autonomy, thus facilitating frequent interference from the central level to the local level either by UNMIK or the Central Government. On the other hand, municipalities did not have legal obligations to implement and fulfill the findings of the Central Government on cases of the lawlessness of the work of municipal bodies.

With the approval of the Kosovo Constitution and the Law on Local Self-Government, the relations between these two levels of power are institutionalized, clearly defining the rights and responsibilities of the Central and Local Government in the process of overseeing the legality of the functioning of local governance organs, as well as the legality of Local Government acts.

These reports in no way undermine the principle of local autonomy, because local government is a constitutional category and enjoys mechanisms of protection of local autonomy even through constitutional judgments in cases when the Central 
Government intervenes in violation of the Constitution and the Law.

\section{General Aspect}

Local Government has as its mission the provision of closer services to citizens and the right of citizens to participate in the conduct of public affairs, which will regulate and manage, under their responsibility and in the interest of the local population, a good part of public affairs (European Charter of Local SelfGovernment, article 3, 1985). The constitution and local laws define the responsibilities of local government, in the exercise of which these governmental authorities have full responsibility and autonomy.

All levels of power have shared responsibilities, they are part of the country's legal and constitutional system as an integral part of government and state functionality. Despite the autonomy of each level of government, with the aim of ensuring legality and constitutional principles, central government bodies have been entrusted with the responsibility of ensuring the legality of the work of local level bodies. Therefore, primary importance is given to the regulation of relations between central and local government, as constitutional and legal reports.

Local governance, especially the decentralization process, is one of the issues addressed in the Ahtisaari Package. This document emphasizes that the decentralization system, the creation and development of new municipalities, will serve as an element to address the concerns of the Serb community and other minority communities in Kosovo, to encourage and ensure active community participation in local government, above all, to fulfill the principles derived from the European Charter of Local SelfGovernment, with particular emphasis on the principle of subsidiarity (Bajrami, 2010, pp 244).

The administration bodies are autonomous in the exercise of their functions and responsibilities within the authorizations, which are provided by law, other provisions and other general acts, therefore the oversight by the highest authorities is intended solely to ensure that the law is being implemented fairly (Sokoli, 2014, pp 42).

Throughout the history of local government development there have been disagreements and antagonisms between levels of power, in particular between central and local government. It is entirely natural for local government efforts to have as much power as possible to limit the central government's intervention, while central government has always expressed the tendency to centralize functions at the central level.

These antagonisms are still present, especially in the totalitarian and transition countries. By comparing the relationship between central government and local government, it is concluded that the vast majority of states have institutionalized and regulated these reports by constitution and laws, in particular with the Law on Local Self Government, as a system law, where exactly these reports are predicted powers.

The institutionalization of the relations between these two levels of power is very important for defining and sharing mutual responsibilities, defining which public issues are in the interest of Local Government and what are in the interests and responsibilities of Central Government. Thus it defines Mutual relations between these levels of power, in particular, sets out the basic principles of administrative oversight, mutual responsibilities, types of administrative review, administrative review procedures, rights of the supervisory authority and municipal authorities, always respecting the objectives of administrative review.

The principle of the autonomy of Local Self-Government, as a basic principle of Local Government, will be respected only when the relations between these two levels of power are defined by the constitution and the law, as this prevents conflicts of power exercise and interventions in responsibilities and powers of one and the other level of power.

Kosovo, after 1999, has gone through two very important stages in the functioning of local and central government. In fact, in the period 1999-2008, when Kosovo was under UN administration, central government was UNMIK's administration, which, in relation to Local Government, cared for overseeing the work of municipal administrators.

The legal basis for the functioning of local government in this period was UNMIK Regulation 45/2000, which has created many problems between local and central government. In fact, supreme power at the local and central level was UNMIK's administration.

The Special Representative of the Secretary-General (SRSG) retained all the powers granted to him under United Nations 
Security Council Resolution 1244 . He had the final say in making decisions regarding any provision of this Regulation (UNMIK regulation $\mathrm{nr} 2000 / 45$ on selfgovernment of municipalities of Kosova, Article 47.1) The SRSG was entitled to annul any municipal decision if it considered it to be in violation of United Nations Security Council Resolution 1244, UNMIK Regulations or other applicable laws and whether those decisions do not take into account to the extent that the rights and interests of communities living in the territory of that commune (UNMIK regulation $\mathrm{nr} 2000 / 45$ on selfgovernment of municipalities of Kosova, Article 47.2)

The period in question is a typical example of the problems and disagreements that might arise between the levels of government, because the UNMIK administration behaved in a dual position: in certain cases it claimed itself as a central power, while in other cases it was responsible attributing to local institutions as central power. This period was characterized by numerous interventions by the central government, both from the local and the international ones, because in the absence of the mechanisms of protection of local autonomy, it intervened in many of the municipality's own competencies, envisaged by UNMIK Regulation No. 45/2000. This situation has caused duality of competences, especially in the field of management of public utilities, in the field of education, health, and other fields and areas, which has caused dissatisfaction and great disputes especially with Local Government in relation to Central Government.

The second phase of Local Self-Government in Kosovo starts with the adoption of the Constitution and the Law on Local SelfGovernment. The relationship between central government and local government, according to the Constitution, is regulated and institutionalized in its entirety in accordance with the principles of the Charter, referring to the relations between these two levels of power.

\section{Constitutional and legal aspects of the relationship between central and local level}

As in most other countries, and in Kosovo, Local SelfGovernment is a constitutional category with powers, responsibilities and autonomy as defined by the Constitution. The Constitution of the Republic of Kosovo guarantees the local government by defining that the municipality is the basic territorial unit of Local Self-Government. Also, the Constitution of the Republic of Kosovo stipulates that the organization and powers of local self-government units are regulated by law
(UNMIK regulation $\mathrm{nr} 2000 / 45$ on selfgovernment of municipalities of Kosova, Article 12.2).

The Constitution of the Republic of Kosovo provides special protection to the Local Self-Government. It envisages special procedures in the adoption and amendment of laws that regulate the organization and competencies of the units of Local SelfGovernment. Article 81.1 of the Constitution of the Republic of Kosovo has defined the model of the double majority in the cases of adoption and amendment of laws that regulate the area of Local Self-Government.

The principles on which the Local Self-Government in the Republic of Kosovo are developed aim at balancing the relations between the central and the local level. According to the Constitution, Local Self-Government is exercised among the elected bodies in the general, equal, free and direct elections and secret ballot (UNMIK regulation $\mathrm{nr}$ 2000/45 on selfgovernment of municipalities of Kosova, Article 123.2). It follows that only the municipal bodies, derived from direct, equal and free elections, can exercise the functions of Local Self-Government. This constitutional definition is promoted and protected by the European Charter of Local Self-Government. Local SelfGovernment bodies, resulting from the electoral process and popular legitimacy, enjoy constitutional judicial protection, administrative protection and other protection, which can be exercised on a regular court course.

According to Article 113.4 of the Constitution, municipalities are authorized to challenge the constitutionality of laws that violate their responsibilities and incomes to the Constitutional Court. This authorization enables municipal bodies to maintain their autonomy and breadth through this remedy. The Constitution of the Republic of Kosovo in Article 123.3 (General Principles) stipulates that "The activity of the bodies of local self-government is based on this Constitution and the laws of the Republic of Kosovo and respects the European Charter on Local SelfGovernment. The Republic of Kosovo considers and applies the European Charter of Local Self-Government to the extent required by the signatory country".

The Constitution of the Republic of Kosovo defines municipalities as core units of Local Self-Government, which enjoy a high degree of Local Self-Government and encourage and ensure the active participation of all citizens in the decisionmaking process of municipal bodies. Also, in Article 124.6 of the 
Constitution, municipalities are obliged to respect the Constitution, the law and enforce judicial decisions. According to the Constitution, the administrative review of municipal acts by central authorities in their area of competence is limited to ensuring compliance with the Constitution of the Republic of Kosovo and with the law.

As evidenced by the constitutional definitions, the basic units of Local Self-Government in Kosovo are municipalities that enjoy a high degree of autonomy and are obliged to ensure citizen participation in decision-making processes. Also, according to the Constitution, the model of the territorial body in Kosovo is based on the model of dual governance, without the existence of intermediate power bodies.

Local government bodies are obliged to respect the Constitution, the Law, and enforce judicial decisions, which imply that they should respect the boundaries of their activity as set out in the Constitution and by law in exercising their functions. Despite the fact that the Constitution of the Republic of Kosovo promotes and guarantees a high degree of substantive autonomy and constitutional judicial protection, however, in accordance with the standards of the European Charter for Local SelfGovernment, it envisages the institute of administrative review of the acts issued by the municipalities, which aim to ensure legality, respectively the compatibility of the acts in question with the Constitution and the Law in force (Constitution of the Republic of Kosovo, 2008, Article 124.7). This administrative review is exercised by the central administration bodies and, as noted above, the objective is only to ensure the compatibility of municipal acts with the Constitution and the Law.

The administrative review, therefore, does not intend to assess the appropriateness and usefulness of municipal acts that regulate areas of municipal competencies, as opposed to delegated competencies where central bodies assess the appropriateness and usefulness of municipal acts regulating delegated competencies. In the context of the direct application of the principles of the European Charter of Local Self-Government and the constitutional spirit, the administrative review should respect the proportional principle, which means that the central supervisory bodies should take measures and actions in proportion to violated violations without affecting substantive issues of local autonomy. As noted above, Article 123 (General Principles) of the Constitution of the Republic of Kosovo stipulates that the right of Local Self-Government is guaranteed and regulated by law. The Assembly of the Republic of Kosovo, in compliance with the constitutional procedures, has adopted the Law No. 03 / L-040 on Local Self-Government.

The Law on Local Self-Government in a Complex manner regulates all segments of Local Self-Government, defining competencies, organs, organization, local government acts and other issues of importance to Local Governance as a fundamental unit of organization of the state where citizens and residents of that Municipalities realize most of their rights and obligations.

The law also regulates the relationship between central and local government, referring to the highest standards of local government and, in general, to consolidated western democracies.

According to the Law on Local Self Government, the Central Government monitors, supports and oversees the work of local government bodies, helping the work of local government bodies to build professional, financial and logistical capacities for the exercise of their functions. However, as noted above, the Central Government has the right and responsibility to take the necessary measures against the local government bodies and in the process of failing local governments to enforce the law and to provide citizens with services. the administrative review has the right to take legal measures in the procedure of reviewing the legality of municipal acts. The Municipal Assembly, as the highest legislative body and municipal representative, has the greatest responsibilities in matters and decisions of interest of local residents. If the Municipal Assembly fails to perform compulsory functions according to the standards set by law or if it becomes dysfunctional and fails to exercise the fundamental rights of the citizens, the responsible ministry notifies the municipality of failures and requires the performance of municipal responsibilities and functions.

Also, the Ministry responsible for Local Government notifies the Government of the Republic of Kosovo for the failure of the municipality. In this case, the Government may dissolve the Municipal Assembly as ineffective and announce new Municipal Assembly Elections (Law on local self-government, Nr. 03/L040, Article 50).

According to the Law on Local Self-Government, the mayor, as the executive executive of the municipality, is elected by direct election in accordance with the Law on Local Elections. The mayor, as the chief executive of the municipality, applies the acts 
and decisions of the Municipal Assembly and proposes to the Assembly for approval. The mayor is elected for a period of four years, but the mandate of the mayor ends as foreseen by law, as well as in the cases of dismissal. The Mayor may be suspended by a decision of the Government of the Republic of Kosovo within a period of 30 days if the President has violated the Constitution and the Law in force. If it considers that the conditions for suspension from the mayor's office have been met, the Ministry responsible for local government recommends to the Government of the Republic of Kosovo the suspension of that mayor. The Government of the Republic of Kosovo (within 30 days) may suspend the decision of the Mayor to submit the case to the Constitutional Court. (Law on local self-government, $\mathrm{Nr}$. 03/L-040, Article 64.2). If the Constitutional Court supports the decision, the Government may dismiss the mayor from office.

A very substantial part of the Law on Local Self-Government in regulating the relations between the Central and Local Government is the municipal administrative oversight and review. The entire Chapter XX of the Law defines the modalities of administrative review of municipal acts.

According to the Law, the municipal administrative review has the following objectives:

a) a) Strengthen the ability of local self-government bodies to fulfill their responsibilities through counseling, support and assistance;

b) b) to ensure the legality of the activities of the bodies of local self-government;

c) Ensure that the rights and interests of citizens are respected (Law on local self-government, Nr. 03/L-040, Article 50).

The administrative review shall be exercised by central bodies in accordance with the Constitution and the principles of the European Charter on Local Self-Government. The Law on Local Self Government in Article 75.1 explicitly provides that the administrative review of municipalities is in accordance with the Constitution and the Law. This administrative review should be proportionate and have as little impact on the interests of Local Self-Government. In principle, the supervisory authority is the Ministry responsible for Local Government, if the responsibility for the supervision of municipalities is not expressly provided by law to the other responsible ministry or institution that deals with specific areas (Law on local self-government, Nr. 03/L-040, Article 76.1).
The delegation of delegated powers is made by the Central Government body, which has delegated those competences. Law on Local Self-Government - As a basic law governing the organization and functioning of Local Government in Kosovo, it also has certain legal competences for MLGA, which include:

- monitoring the exercise of enhanced competencies in accordance with applicable legislation in the Republic of Kosovo (Law on local self-government, Nr. 03/L-040, Article 76.2);

- oversee the legality of partnership decisions;

- review of draft agreements on cross-border cooperation of municipalities;

- issuing guidelines for cooperation agreements of municipalities with villages, settlements and urban quarters;

- Notification of the Government of the Republic of Kosovo for non-functioning of the municipality;

- recommends to the Government of Kosovo the suspension of the Mayor;

- the right to oversee municipalities, enforce the law, ensure respect for the rights and interests of citizens, and to strengthen and enable municipal bodies to fulfill the legal mandate;

- mandatory review of the legality of municipal acts and provision of preliminary consultations prior to the issuance of the act;

- Preparation and publication of annual report on activities related to the supervision of municipalities in the previous year by the end of March (Law on local self-government, Nr. 03/L-040, Article 29.4, 50.3, 64.2, 74, 76, 81, 83).

As noted above, the administrative review in the areas of personal and extended competencies of municipalities is limited to the review of legality, while in the field of delegated competences it is subject to oversight of the legality and appropriateness of the actions. The law provided for regular review of legality and mandatory review of legality, procedure for review of legality, requests for prior consultation, review of suitability and citizens' complaints.

This research paper, in the following chapters, based on the facts and official data of the Ministry responsible for Local Governance, in various reports of relevant institutions, in detail, supported by statistical facts, will elaborate separately all these forms of administrative review, as a very important segment of the relationship between the Central and Local Government.

The Law on Local Government Finance - which regulates the powers for municipal financial resources - provides that the ministries responsible for the respective area to which delegated or enhanced competences belong to will monitor and ensure that 
these competences are exercised in accordance with laws, sublegal acts and relevant standards, as well as measures taken by the municipality to exercise these competencies are appropriate (Law on local finance, Nr.03/L-049, Article 34).

Law on Municipal Administrative Boundaries - This Law regulates the territorial organization of the Local SelfGovernment of the Republic of Kosovo, establishes new municipalities, defines the territory and administrative boundaries of the municipalities, making the Government of Kosovo indirectly liable to the Ministry of Administration Local Government, especially in the case of the creation of new municipalities (Law on administrative borders of municipalities, Nr. 03/L-041, Article 14.)

In the process of administrative review, the supervisory and municipal authorities are obliged to cooperate with one another. The supervisory authority shall take all measures undertaken on the basis of the law and explain the reasons for the implementation of a measure in a particular supervision. Also, municipal bodies, if they consider that the supervisory authority has exceeded the legal powers, has the right to initiate the judicial protection case before the competent courts.

\section{Conclusions and Recommendations}

From what has been said above, it can be estimated that the relationship between the Central and Local Government is very complex and of particular sensitivity to the fact that we are dealing with the institutional relations of two levels of power, the harmonious functioning of which the functioning of the entire legal and constitutional system of the country is also determined. Given the importance of this issue, the European Charter of Local Self-Government, in its most substantive part, regulates the relationship between Central and Local Government. This card commits the parties to apply the basic rules that guarantee the political, administrative and financial independence of local authorities. It demonstrates at the European level the political will to bring to life, at all levels of territorial administration, the fundamental principles of the European Charter of Local SelfGovernment.

According to this charter, the administrative control of the activity of local activities is based on these principles: any administrative control over the local authorities may be exercised only according to the procedures and in those cases that are provided in constitutions or in laws; any administrative control of the activities of local authorities should normally only seek to ensure compliance with the law and constitutional principles; administrative control of local authorities is exercised by ensuring that the intervention of the controlling authority is proportionate to the importance of the interests which are intended to protect it.

The Constitution of the Republic of Kosovo, the Law on Local Self-Government and other laws, guarantees local governments a high level of local autonomy, in full compliance with the principles of the European Charter on Local Self-Government. In fact, the Constitution of the Republic of Kosovo has directly accepted the constitutional issue of the European Charter for Local Self-Government, as evidence and commitment of Kosovo to build a local government system with European standards.

According to the Constitution, municipalities are authorized to challenge the constitutionality of laws that violate their responsibilities and incomes in the Constitutional Court. This authorization enables municipal bodies to maintain their autonomy and breadth through this remedy.

Based on the assessments and conclusions reached during the study, analysis and processing of statistical data, professional elaborations, taking into account the constitutional and legal determinants and the mission as well as the purpose of the administrative oversight, propose these recommendations:

- Improvement and further advancement of the monitoring system of municipalities, both through direct participatory monitoring in municipalities and through electronic monitoring, which is realized through various forms, in particular through "telepresence";

- Despite the fact that the Ministry of Local Government Administration has built up an adequate electronic monitoring system, it should be borne in mind that this way of monitoring the work enables only faster identification of problems and their easier handling. Only the identification of legal violations during electronic monitoring is insufficient unless it is accompanied by concrete measures to address legal violations;

- Advance and stimulate local and central level communication at the stage of drafting municipal acts by submitting the draft act to the oversight body to ensure it is in compliance with the law. In this way, the Municipal Assembly is assured for the legality of the act voted and approved in the Municipal Assembly;

- As noted in this paper, the provisions of the Law on Local Self-Government, referring to the relationship between local and central level, do not create mechanisms for an unlawful act to be enforced until the final court decision. 
The current legal choices do not allow the possibility of suspensive measures by the supervisory authorities in cases of violation of legality and constitutionality to stop the consequences that may arise from the implementation of such act. This situation creates the need in the future, through legal changes, to provide for the right of the supervisory authority to abolish and abolish municipal acts contrary to the Constitution.

\section{References}

1. Bajrami, A. (2011). Sistemi Kushtetues i Republikës së Kosovës. Prishtinë: Kolgji AAB

2. Sokoli, A. (2014). E Drejta Procedurale Administrative. Prishtinë.

3. Constitution of the Republic of Kosovo

4. European Charter of Local Self-Government, Article 3, Council of Europe, 1985

5. Law on local finance, Nr.03/L-049

6. Law on administrative borders of municipalities, $\mathrm{Nr}$. 03/L-041

7. Law on local self-government, Nr. 03/L-040.

8. UNMIK regulation nr. 2000/45 on sef-governmnet of municipalities of Kosovo 